\title{
SPOROTRIKOSIS LIMFOKUTAN DIAGNOSIS HISTOPATOLOGI DAN SITOLOGI
}

\author{
${ }^{1}$ Poppy M. Lintong \\ ${ }^{2}$ Inneke V. Sumolang \\ ${ }^{1}$ Bagian Patologi Anatomi Fakultas Kedokteran Universitas Sam Ratulangi Manado \\ ${ }^{2}$ Bagian Ilmu Kesehatan Kulit dan Kelamin Fakultas Kedokteran \\ Universitas Sam Ratulangi Manado \\ Email: magda_plin@yahoo.com
}

\begin{abstract}
Diagnosis of sporotrichosis associated with lymphocutaneous nodules was made based on the histopathological examination of skin lesions and the cytology of fine needle aspiration biopsy (FNAB). A case of sporotrichosis in a 63-year-old man was reported with papules and nodules spread along the back of the left hand, forearm, and arm. The histopathological examination showed infiltration of PMNs, granulomas, and giant cells in the dermis and epidermis, along with hyperplasia and microabscesses. Sporothrix schenckii was not found in the skin lesion tissues. However, in the FNAB cytology examination of lymphocutaneus nodules we found spores of Sporothrix schenckii in the cytoplasma of histiocytes besides granuloma and infiltration of PMNs.
\end{abstract}

Keywords: sporothrix schenckii, histopathology, FNAB cytology

\begin{abstract}
Abstrak: Diagnosis sporotrikosis kulit dengan nodul limfokutan ditegakkan melalui pemeriksaan histopatologi pada lesi kulit dan sitologi biopsi aspirasi jarum halus pada nodul limfokutan. Kami melaporkan kasus sporotrikosis pada laki-laki berusia 63 tahun dengan papulpapul dan nodul-nodul eritematosa pada dorsum manus, antebrakium, dan brakium sinistra. Pemeriksaan histopatologi jaringan biopsi dari lesi kulit menunjukkan reaksi radang, gambaran granuloma, dan sel datia dalam dermis dan epidermis, dengan mikroabses disertai hiperplasia. Tidak ditemukan jamur Sporothrix schenckii dalam potongan jaringan histopatologi. Hasil pemeriksaan sitologi biopsi aspirasi jarum halus pada nodul limfokutan memperlihatkan adanya spora-spora jamur Sporothrix schenckii dalam sitoplasma sel-sel histiosit disamping terdapatnya bentuk granuloma dalam infiltrat radang.
\end{abstract}

Kata kunci: sporothrix schenckii, histopatologi, sitologi biopsi aspirasi jarum halus.

Sporotrikosis adalah infeksi kronik yang disebabkan oleh jamur Sporothrix schenckii, ${ }^{1-3}$ paling sering ditemukan pada lakilaki dewasa dan umumnya menunjukkan infeksi yang terlokalisasi pada kulit dan saluran limfatik. Walaupun sangat jarang, penyakit ini dapat berkembang menjadi sporotrikosis sistemik. ${ }^{1}$

Infeksi dengan jamur Sporothrix schenckii tersebar secara luas di dunia. ${ }^{1}$ Sporotrikosis asimtomatik (didiagnosis melalui tes kulit) dijumpai pada lebih dari $10 \%$ po- pulasi di daerah-daerah tertentu seperti Lousiana dan Arizona. ${ }^{2,3}$ Infeksi sering berkaitan dengan pekerjaan dan terutama pada laki-laki dewasa, walaupun dapat juga ditemukan pada anak-anak. Sporotrikosis juga dapat menyebar sporadik, dan pernah dilaporkan dapat terjadi penyembuhan spontan. ${ }^{1}$

Secara klinis sporotrikosis dapat dibagi atas dua bentuk yaitu sporotrikosis kulit primer dan sporotrikosis sistemik. Kedua bentuk ini terjadi akibat inokulasi jamur Sporothrix schenckii secara langsung pada tempat 
yang mengalami trauma kecil. ${ }^{2}$

Reaksi-reaksi kulit pada sporotrikosis kulit primer dibagi atas tiga jenis yakni lymphocutaneous (yang tersering), localized (fixed) cutaneous, dan disseminated cutaneous. Pada sporotrikosis limfokutan (lymphocutaneous) terjadi lesi di tempat inokulasi sesudah terkontak jamur Sporothrix schenckii dengan periode inkubasi beberapa hari sampai beberapa minggu. ${ }^{1}$ Biasanya lesi awal berbentuk papul yang tidak nyeri pada jari-jari atau tangan, kemudian timbul ulserasi dan dapat meluas sebagai suatu bercak verukosa yang berkrusta. Selanjutnya jamur Sporothrix schenckii akan menyerang saluran limfatik, ditandai dengan terbentuknya nodul sekunder asimtomatik sepanjang garis drainase limfatik, dan dapat disertai pembesaran kelenjar getah bening regional. Nodul limfatik juga dapat mengalami supurasi kemudian ulserasi. ${ }^{1,2}$ Bentuk sporotrikosis kulit lokal terfiksasi (localized (fixed) cutaneous) terlihat sebagai bercak tunggal paling sering pada lengan atau wajah dengan permukaan verukosa yang berkrusta, tanpa kecenderungan menyebar melalui saluran limfatik. ${ }^{1}$ Jenis ini mencerminkan adanya tingkat imunitas yang cukup tinggi. ${ }^{1}$ Bentuk sporotrikosis kulit yang menyebar (disseminated cutaneous) lebih jarang ditemukan, namun telah dilaporkan terdapatnya bentuk ini pada penyandang AIDS. ${ }^{1}$

Sporotrikosis sistemik lebih jarang terjadi dan biasanya menyertai infeksi paru seperti tuberkulosis, terutama pada yang mempunyai respons imun rendah seperti pada penderita limfoma maligna, terapi kortikosteroid jangka panjang (sebagai imunosupresif), alkoholik, sarkoidosis, diabetes melitus, dan dapat menyebar ke organ lain pada penderita AIDS yang terinfeksi dengan HIV. ${ }^{1,2}$ Dapat juga terjadi pada organ-organ visera tanpa adanya lesi kulit. ${ }^{1}$ Sporotrikosis sistemik dapat ditenukan unifokal atau multifokal. Sporotrikosis sistemik unifokal dapat menyerang paru, sendi-sendi tunggal atau bilateral, saluran genitourinaria, dan lebih jarang lagi otak. Sporotrikosis sistemik multifokal menunjukkan penyebaran lesi kulit secara luas yang diawali dengan satu nodul atau abses subkutan yang kemudian mengalami ulserasi. Umumnya terjadi pada sendi dari beberapa ekstrimitas. ${ }^{2}$

Melalui pemeriksaan histopatologi jaringan, spora jamur Sporothrix schenckii tidak dapat dilihat dengan pewarnaan konvensional (hematoxylin eosin), namun paling baik ditunjukkan dengan pewarnaan PAS (Periodic Acid Schif), atau methenamine silver. ${ }^{1-4}$ Spora berbentuk bulat sampai oval ukuran diameter 4-6 $\mu \mathrm{m}$ dengan tonjolan tunggal atau ganda, kadang-kadang hifa-hifa nonsepta. ${ }^{1-3}$ Jika jamur tidak ditemukan pada potongan jaringan maka diagnosis sporotrikosis hanya sampai tahap dicurigai; dalam hal ini sebaiknya dikonfirmasi dengan pemeriksaan isolasi, kultur organisme, atau dapat juga melalui pemeriksaan imunohistokimia. 1,2 Zaharopoulos melaporkan satu kasus sporotrikosis limfokutan yang didiagnosis melalui pemeriksaan sitologi biopsi aspirasi jarum halus pada nodul limfokutan. Pada pemeriksaan sitologi dapat dideteksi spora-spora jamur Sporothrix schenckii berbentuk bulat dan oval ukuran diameter $4-8 \mu \mathrm{m}$, biasanya dengan budding, teardrop, atau pipestem dalam eksudat radang dan makrofag, juga ditemukan asteroid bodies. ${ }^{5}$

Gambaran histopatologi sporotrikosis kulit primer lesi awal menunjukkan adanya infiltrasi sel-sel radang tidak spesifik terdiri dari sel-sel netrofil, sel limfosit, sel plasma, dan histiosit. Pada lesi-lesi verukosa yang berlangsung lama tampak adanya hiperplasia epidermis, infiltrasi limfoplasmatik dermal dan intraepidermal, disertai mikroabses dan granuloma-granuloma kecil, sel-sel eosinofil, sel-sel datia, dan badan asteroid. Badan asteroid sering ditemukan pada kasus sporotrikosis di Afrika Selatan, Jepang, dan Australia dengan insidens 39-65\%; juga pernah dilaporkan pada beberapa kasus sporotrikosis yang terjadi di Amerika Serikat. Karakteristik reaksi radang dalam dermis terdiri dari tiga zona: zona supuratif/ sentral yang terdiri dari nekrosis, debris seluler, dan sel-sel netrofil; zona tuberkuloid/tengah yang terdiri dari sel-sel epiteloid dan sel datia; dan zone roundcell/luar yang terdiri sel-sel limfoid dan sel- 
sel plasma. Gambaran histopatologi dari nodul limfatik serupa dengan nodul primer pada kulit. ${ }^{2-4}$ Pengobatan sporotrikosis dengan anti-fungal golongan azol seperti itrakonazol merupakan pilihan utama. Beberapa laporan kasus sporotrikosis dengan pengobatan itrakonasol menunjukkan hasil yang cukup memuaskan, terutama pada bentuk terlokalisasi walaupun harus dengan dosis itrakonazol yang lebih besar dan memerlukan waktu berbulan-bulan. ${ }^{6,7}$ Sporotrikosis sistemik multifokal dapat diobati dengan potassium iodide yang diberikan tunggal atau kombinasi dengan amphotericin $B .^{3}$

\section{LAPORAN KASUS}

Seorang laki-laki berusia 63 tahun, suku Jawa, pekerjaan tukang bangunan yang berdomisili di daerah pedesaan datang ke Bagian Penyakit Kulit dan Kelamin RSU Prof.Dr.R.D.Kandou pada tanggal 26 April 2007. Sebelum timbul benjolan, penderita pernah mengalami luka kecil akibat terke-na palu-palu saat bekerja. Luka tersebut sembuh, tetapi kemudian pada bekas luka timbul benjolan yang pertama kali. Benjolan tersebut membesar dan kemudian pecah. Benjolan juga menyebar membentuk garis lurus. Pada pemeriksaan klinik status dermatologi pada daerah dorsum manus, antebrakium, dan brakium sinistra sinistra ditemukan papul, nodul eritematosa dan multipel, ulkus berukuran 1-3 cm yang ditutupi dengan krusta coklat kehitaman, sebagian permukaan tampak basah, terdapat lesi satelit berupa papul eritematous mengelilingi ulkus. (Gambar 1).

Terdapat juga nodul di daerah garis lurus dari dorsum manus ke arah daerah kubiti sinistra mengikuti aliran limf (nodul limfokutan). Dilakukan biopsi jaringan pada daerah tersebut dan sampel dikirim ke Laboratorium Patologi Anatomi Fakultas Kedokteran Universitas Sam Ratulangi untuk pemeriksaan histopatologi; juga dilakukan pemerikaan sitologi biopsi aspirasi jarum halus pada nodul limfokutan di daerah lengan bawah (Gambar 2).

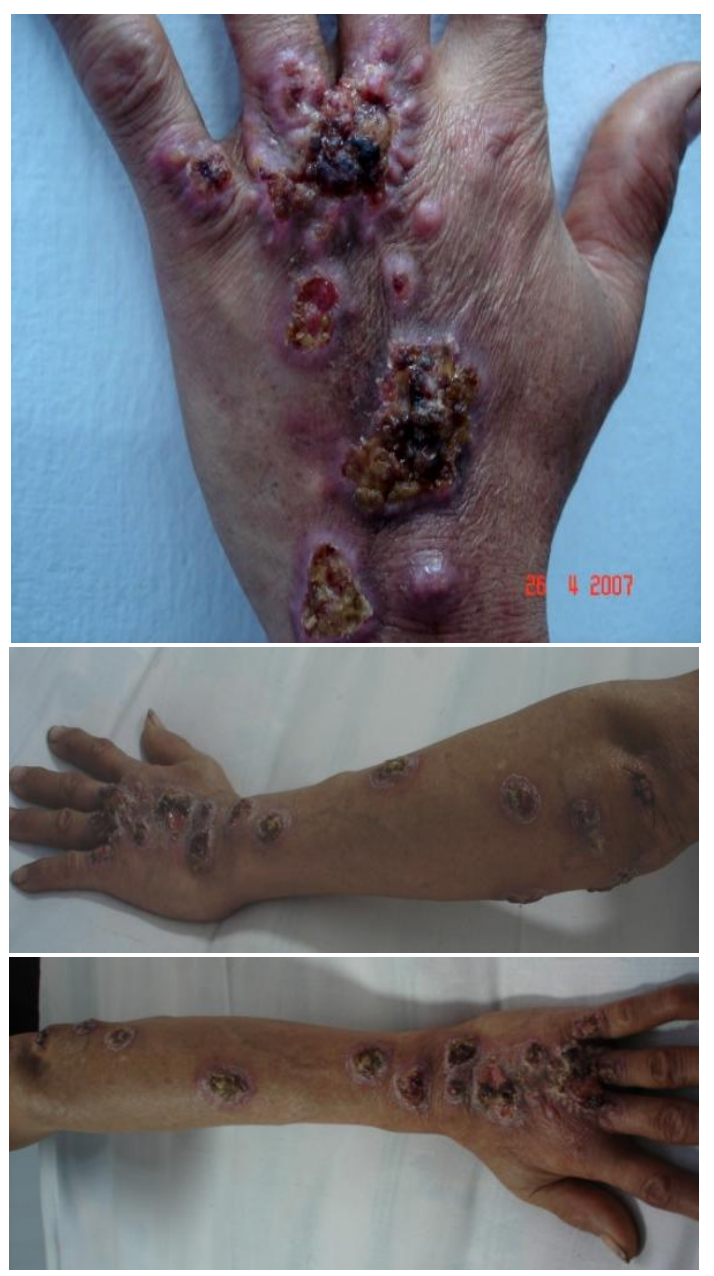

Gambar 1. Status dermatologi lesi primer sporotrikosis (kiri) terdiri dari nodul dan papul eritematous dengan ulserasi dan krusta pada permukaaan dan nodul limfokutaneus (kanan) mengikuti drainase aliran limfe kearah kubiti.

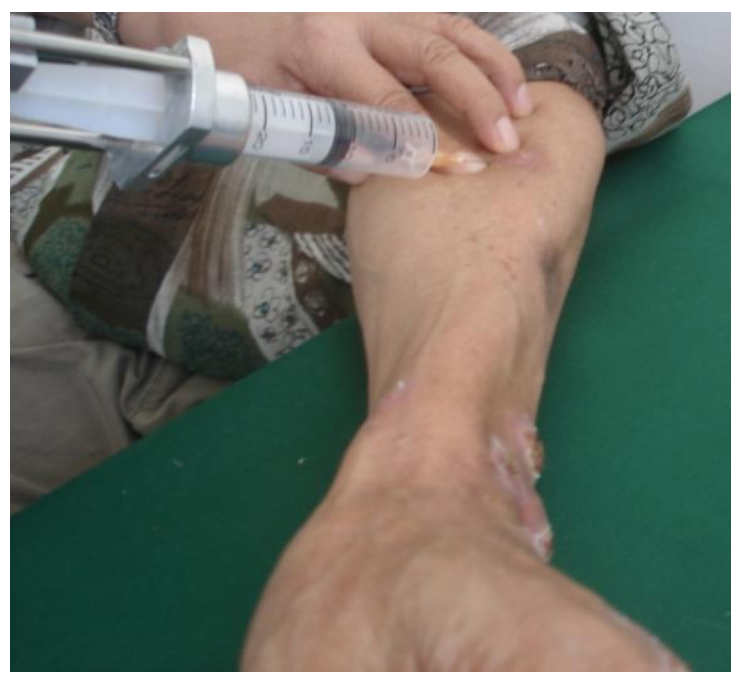

Gambar 2. Biopsi aspirasi jarum halus pada nodul limfokutan di daerah antebrakium 
Pada tanggal 4 Mei 2007 hasil diagnosis histopatologi adalah infeksi jamur Sporothrix schenckii (sporotrikosis). Demikian pula pada tanggal 3 Juni 2007 hasil kultur jaringan dari Laboratorium Mikrobiologi FK Unsrat menunjukkan adanya jamur Sporothrix schenckii.

Pada kasus ini diberikan pengobatan topikal dengan kompres $\mathrm{NaCl} 0,9 \%$ dan asam fusidat serta pengobatan sistemik dengan itrakonasol $200 \mathrm{mg}$ selama 12 bulan yang dibagi dengan pengobatan kontinyu $200 \mathrm{mg}$ setiap hari selama 8 bulan. Pada bulan-bulan awal pengobatan terlihat hasil yang membaik dengan ulserasi mengering, sebagian nodus sembuh, dan tidak dijumpai nodus baru. Setelah mengalami perbaikan dengan delapan bulan pengobatan itrakonazol $200 \mathrm{mg}$ setiap hari, penderita tidak kembali kontrol selama tiga bulan. Pada kunjungan setelah tiga bulan, penderita datang dengan keluhan adanya nodul baru dan timbul benjolan-benjolan pada bekas luka dan benjolan lama. Penderita diberikan pengobatan pulse therapy dengan itrakonasol 2 x $200 \mathrm{mg}$ sampai empat denyut. Beberapa nodul tampak membaik dan ulserasi sembuh, namun beberapa nodul hanya tampak mengecil tetapi tidak hilang. Setelah tiga bulan tidak datang berobat, timbul lagi benjolan dan luka baru sama seperti pada kunjungan kedua.

Biopsi aspirasi jarum halus dilakukan pada nodul limfokutan, dibuat beberapa sedian hapusan yang difiksasi dengan alkohol 95\%, kemudian diwarnai dengan pengecatan Papanicolau. Hasil pemeriksaan sitologi biopsi aspirasi jarum halus pada nodul limfokutan di daerah antebrakium sinistra tersebut tanggal 26 April 2007 memperlihatkan gambaran mikroskopik sediaan apus yang terdiri dari banyak sel-sel radang yaitu sel-sel limfosit, sel plasma, PMN (netrofil), dengan di antaranya terdapat granuloma selsel epiteloid bercampur dengan sel-sel radang PMN, dan sel plasma. Tampak juga sel-sel datia dan spora-spora jamur Sporothrix schenckii berbentuk oval dengan tonjolan/budding; sebagian terlihat seperti karangan bunga, yang terutama berada dalam histiosit. (Gambar 3 dan 4).
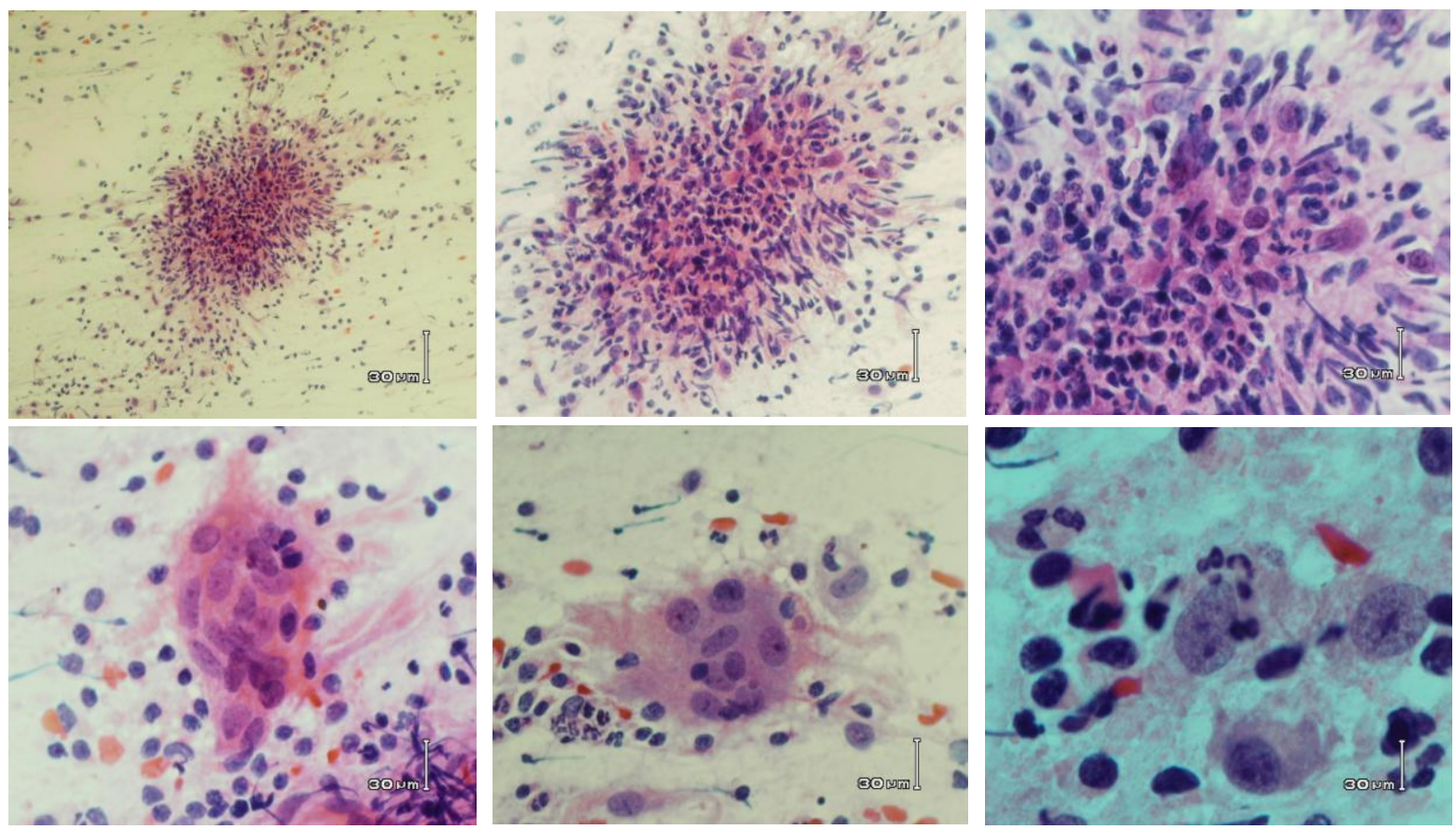

Gambar 3. Gambaran mikroskopik hasil pemeriksaan sitologi biopsi aspirasi jarum halus pada nodul limfokutan antebrakium terdiri dari bentuk granuloma (atas) dalam infiltrat radang, juga sel-sel radang limfosit, PMN, sel plasma, dan sel-sel datia (bagian bawah kiri dan tengah), serta sel-sel makrofag dan histiosit (kanan bawah). 

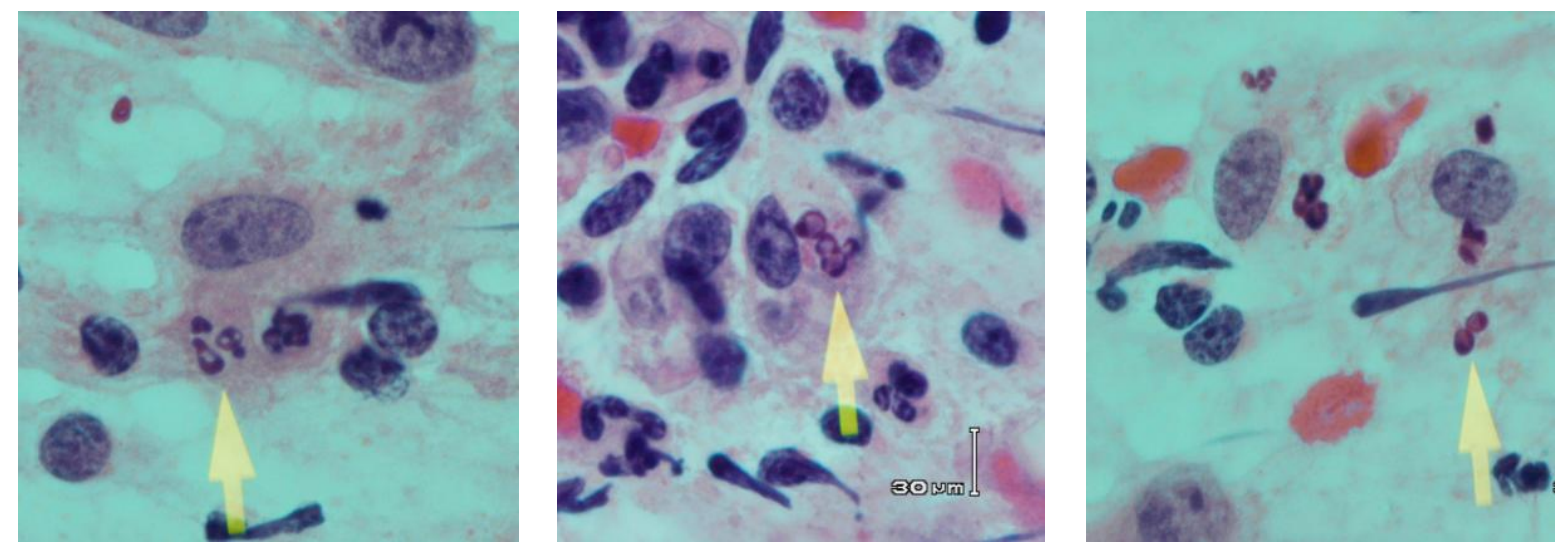

Gambar 4. Gambaran mikroskopik hasil pemeriksaan sitologi biopsi aspirasi jarum halus yang menunjukkan spora-spora jamur Sporothrix schenckii berada didalam sitoplasma sel-sel histiosit, lihat tanda panah (pembesaran $1000 \mathrm{x}$ ).

Hasil pemeriksaan histopatologi jaringan biopsi kulit pada tanggal 4 Mei 2007: Makroskopik diterima sepotong jaringan ukuran $0,5 \times 0,5 \times 0,5 \mathrm{~cm}$, warna putih keabuan, berkonsistensi kenyal. Pada pengecatan konvensional menggunakan hematokslin eosin gambaran mikroskopik memperlihatkan jaringan kulit dilapisi epidermis dengan hiperplasia dan papilomatous ringan, serta mikroabses intraepidermal. Pada dermis tampak infiltrasi sel-sel limfosit, lekosit PMN, sel plasma, granuloma yang terdiri dari sel-sel epiteloid dan sel datia, serta pembuluh darah kapiler. Sel-sel radang ditemukan sampai pada dermis bagian bawah. Tidak ditemukan spora jamur dalam potongan jaringan. (Gambar 5,6).

\section{PEMBAHASAN}

Sporotrikosis kulit primer (paling sering muncul sebagai sporotrikosis limfokutan) lebih sering terjadi dibandingkan dengan sporotrikosis sistemik. ${ }^{1-3}$ Secara klinis kasus ini (Gambar 1) sudah didiagnosis sebagai sportrikosis meskipun pemeriksaan histopatologi jaringan biopsi dari lesi kulit pada tanggal 4 Mei 2007 (Gambar 2,3) hanya menunjukkan reaksi radang dalam dermis, mikroabses intraepidermal, hiperplasia epidermis, papilomatosa dan ulserasi, dan ditunjang oleh adanya gambaran granuloma seperti sel-sel epiteloid dan sel datia. Hal ini sesuai dengan pustaka acuan yang menyebutkan bahwa pada lesi kulit primer dapat terjadi hiperplasia epidermal dengan papil- omatosa dan ulserasi, mikroabses netrofilik intraepidermal, infiltrasi dermal dengan selsel radang limfosit, sel plasma, dan PMN, serta sel epiteloid dan sel datia ${ }^{1-3}$.
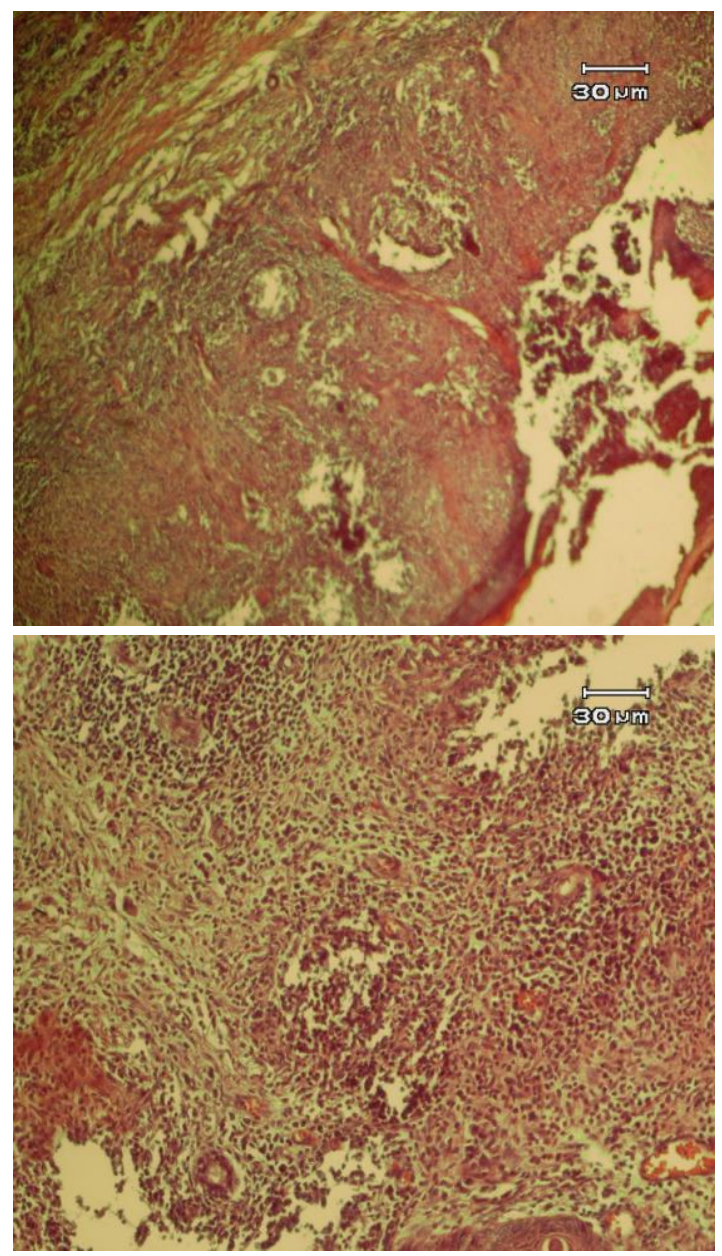

Gambar 5. Gambaran mikroskopik jaringan biopsi kulit, pada bagian atas tampak hiperplasia epidermis dan mikroabses intraepidermal, pada bagian dermis (bawah) terlihat granuloma dalam infiltrat radang. 

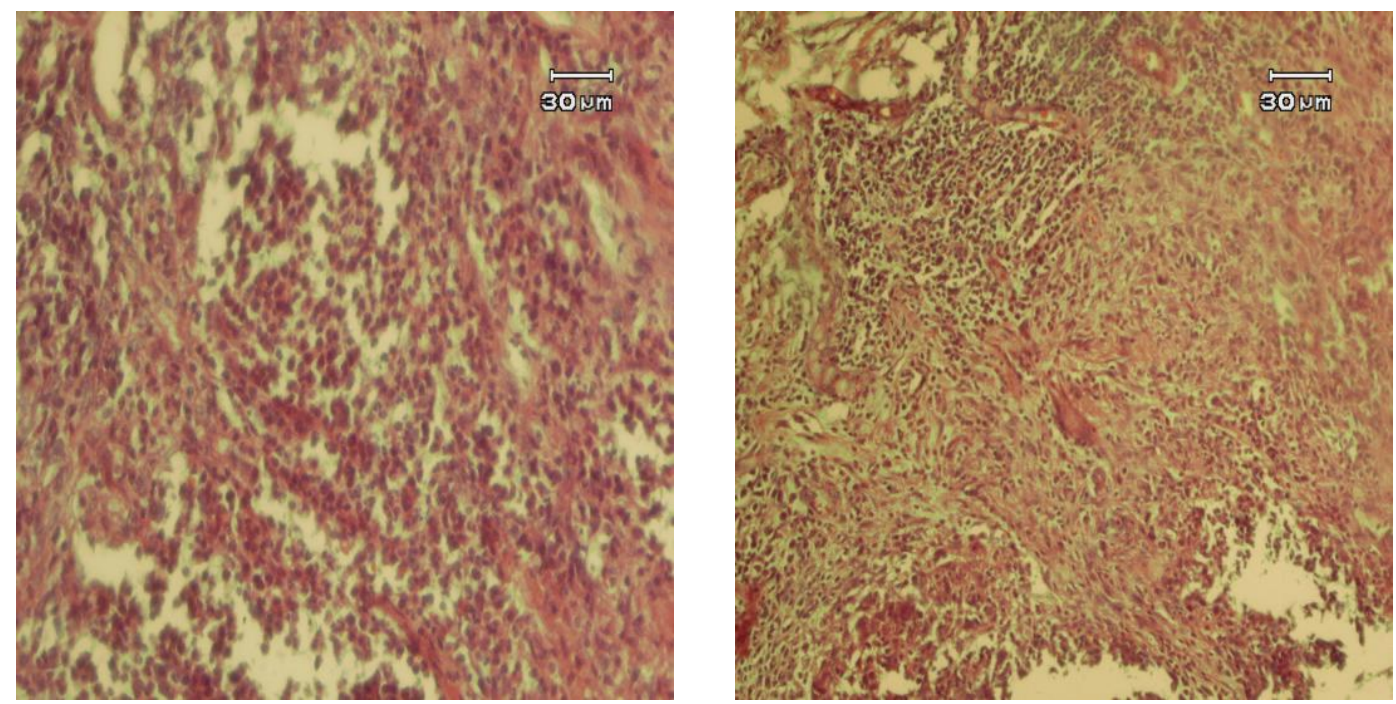

Gambar 6. Gambaran granuloma (pembesaran $400 \mathrm{x}$ ) dalam infiltrat radang lmfosit, PMN, sel plasma, histiosit dan makrofag, pada sebelah kiri dan sebelah kanan terlihat satu sel datia dalam granuloma.

Pada penderita ini tidak ditemukan badan-badan asteroid dalam potongan jaringan, walaupun dalam kepustakaan disebutkan bahwa badan-badan asteroid telah diamati pada beberapa kasus sporotrikosis yang terjadi di Amerika Serikat, Afrika Selatan, dan Australia. Dengan pewarnaan hematoksilin eosin dalam sampel jaringan badan asteroid merupakan suatu badan yang terdiri dari spora berukuran diameter 5$10 \mu \mathrm{m}$ terletak sentral dikelilingi oleh pemanjangan radial dari bahan eosinofilik homogen dengan ukuran diameter 7$25 \mu \mathrm{m} .{ }^{2,3}$ Pada kasus ini walaupun tidak ditemukan badan asteroid, kesimpulan yang diambil sebagai sporotrikosis ditegaskan oleh adanya pemeriksaan kultur jaringan pada tanggal 3 Juni 2007 yang menunjukkan spora jamur Sporothrix schenckii positif.

Hasil pemeriksaan histopatologi dengan pengecatan konvensional (hematoxylin eosin) tidak memperlihatkan adanya spora jamur Sporothrix. Hal ini sesuai dengan pustaka acuan yang menyatakan bahwa spora-spora jamur Sporothrix schenckii tidak dapat dilihat melalui pemeriksaan histopatologi jaringan. ${ }^{1-3}$ Spora jamur tidak mudah terlihat dengan pewarnaan konvensional (hematoxylin eosin), tetapi paling baik ditunjukkan dengan pewarnaan PAS, atau methenamine silver. Dengan meng- gunakan kedua pewarnaan khusus di atas dapat meningkatkan frekuensi penemuan spora jamur. ${ }^{2,3}$ Juga disebutkan bahwa jika spora jamur tidak ditemukan pada potongan jaringan, maka diagnosis sporotrikosis hanya dapat dicurigai. Pada kasus-kasus yang meragukan dapat dilakukan tes kulit sporotrikosis. ${ }^{2,3}$ Pendapat lain menyatakan bahwa hal ini harus dikonfirmasi dengan isolasi dan kultur mikro-organisme atau pemeriksaan imunohistokimia. ${ }^{1}$ Pada penderita ini tidak dilakukan pewarnaan khusus maupun imunohisto-kimia tetapi telah dikonfirmasikan dengan pemeriksaan kultur jamur yang menunjukkan hasil positip, sehingga diagnosis sporotrikosis tidak diragukan lagi. Sporothrix schenckii lebih mudah tumbuh dalam media Sabouraud. Pada suhu ruangan jamur tersebut tumbuh dalam bentuk mycelial dengan conidiophores yang menghasilkan conidia berbentuk 'buket' (karangan bunga). Pada suhu $37^{\circ} \mathrm{C}$, jamur ini tumbuh dalam bentuk ragi. ${ }^{2,3}$ Biakan kultur merupakan baku emas untuk menentukan diagnosis pasti sporotrikosis karena dapat menentukan agen penyebab. ${ }^{8,9}$

Zaharopoulos yang pertama kali melaporkan kasus sporotrikosis dengan diagnosis yang ditegakkan melalui pemeriksaan sitologi biopsi aspirasi jarum halus pada 
nodul limfokutan. ${ }^{5}$ Hasil pemeriksaan menunjukkan spora-spora jamur Sporothrix seperti ragi berbentuk bulat atau oval dengan tonjolan seperti teardrop atau pipestream tunggal dan ganda yang berada dalam eksudat radang dan makrofag; juga ditemukan badan-badan asteroid yang karakteristik untuk sporotrikosis. ${ }^{5}$ Mengacu pada hasil laporan pemeriksaan dari Zaharopoulos maka pada penderita ini juga dilakukan pemeriksaan sitologi biopsi aspirasi jarum halus pada nodul limfokutan antebrakium (Gambar 2).

Hasil pemeriksaan sitologi (Gambar 4 dan 5) menunjukkan bentuk radang granuloma dalam infiltrat sel-sel radang limfosit, PMN, sel, plasma, makrofag, histiosit, dan sel-sel datia. Bentuk granuloma menunjukkan tiga zona (Gambar 4) yang sesuai dengan pustaka acuan yaitu zona supuratif/sentral terdiri dari nekrosis, debris seluler, dan sel-sel netrofil; zona tuberkuloid/tengah terdiri dari sel-sel epiteloid, sel datia, dan zona luar/round-cell terdiri sel-sel limfoid dan sel-sel plasma. Gambaran histopatologi dari nodul limfatik sama dengan nodul primer pada kulit. ${ }^{2-4}$ Pada kasus ini dengan pemeriksaan sitologi juga tidak ditemukan badan asteroid. Namun spora-spora jamur seperti ragi dengan tonjolan tunggal atau ganda, kadang berbentuk seperti buket dapat dilihat didalam sitoplasma sel-sel radang histiosit (Gambar 5). Hal ini sesuai dengan kepustakaan yang menyebutkan bahwa spora jamur dapat ditemukan didalam eksudat radang walaupun lebih sering terdapat di dalam histiosit (intrasito-plasma). ${ }^{1-3,5}$

Sampel biopsi aspirasi jarum halus yang diperoleh dari nodul limfokutan ternyata dapat mendeteksi adanya spora-spora jamur Sporothrix schenckii, sehingga dengan demikian sarana pemeriksaan sitologi biopsi aspirasi jarum halus dapat digunakan untuk identifikasi jamur yang pada pemeriksaan histopatologi jaringan tidak terdeteksi.

\section{KESIMPULAN}

Telah dilaporkan kasus sporotrikosis kulit bentuk limfokutan pada seorang lakilaki dewasa dengan papul-papul dan nodulnodul eritematous serta ulseratif pada dorsum manus, antebrakium, dan brakium sinistra. Diagnosis pasti sporotrikosis ditegakkan melalui pemeriksaan histopatologi, kultur jaringan, dan pemeriksaan sitologi biopsi aspirasi jarum halus dari nodul limfokutan.

Pada kasus-kasus dengan pemeriksaan jaringan biopsi yang tidak spesifik untuk sporotrikosis serta tidak ditemukannya spora jamur, pemeriksaan sitologi biopsi aspirasi jarum halus dari nodul-nodul subkutan dapat dipakai sebagai sarana untuk mengidentifikasi spora-spora jamur tersebut seperti yang telah dilakukan pada kasus ini.

\section{DAFTAR PUSTAKA}

1. Philip MH, Eduardo C, Granter SR. Pathology of the skin with clinical correlation. Vol. I. $.3^{\text {rd }}$ ed. Elsevier Mosby. 2005. p.974-976.

2. David EE. Lever's histopathalogy of the skin. Ninth edition. Lippincott Williams \& Wilkins. 2005. p.625-626.

3. Walter LF, Schaumburg-Lever Gundula. Histopathology of the skin. $6^{\text {th }}$. ed. Philadelphia: J.B.Lippincott Company, 1983; p. 346-347.

4. Hood AF, Kwan HT, Mihm MC, Thomas HD. Primer of dermato-pathology. Second edition. Boston/ Toronto/London: Little Brown and Company, 1993; p. 268269.

5. Paul Z. Fine-needle aspiration cytologic diagnosis of lymphocutaneous sporotrichosis: a Case Report. Diagnostic Cytopathology. 1999; 20: 74-77.

6. Hong SJ, Chang CH, Sporotrichosis on face successfully treated with itraconazole-a case report. Tzu Chi Med J. 2006; 18: $225-8$.

7. Larone DH, Sporothrix schenckii. Medically important fungi. A guide to identification: edisi ke-2. New York, 1987: 78-9.

8. Hay RJ. Deep fungal infections. Dalam : Fredberg IM, Eisen AZ, Wolff K, Austen KF, Goldsmith LA, Katz SI, editor. Fitzpatrick's dermatology in general medicine; edisi ke-7. New York: McGraw-Hill, 2008: 1831-2. 
9. Kwon-Chung KJ. Sporotrichosis. Medical mycology; edisi ke-3. Philadelphia: W.B. Saunders Company, 1992: 707-27.

10.Koga T, Duan H, Urabe K. Immunohistochemical localization of activated and mature CD83+ dendritic cells in granulomas of sporotrichosis. European Journal of Dermatology. 2001; 11(6): 527-529. 